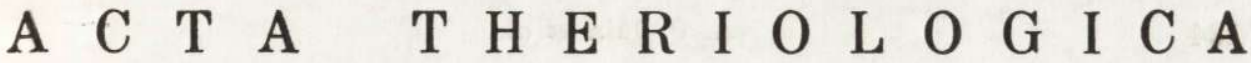

VOL, $20,11: 133-140$.

April, 1975

\author{
A. P. J A I N, Ishwar PR A KA S H \& B. D. R A NA
}

\section{Morphological Variation in the Rats Inhabiting the Indian Desert}

[With 4 Tables]

\begin{abstract}
A comparison of external body parts and cranial characters in three populations of Cutch rock-rat, Rattus c. cutchicus (W r ough to n, 1912) and Soft furred field-rat, $R$. meltada pallidior (R y le y, 1914) collected from their respective habitats in the Indian desert, has been made. In $R$. c. cutchicus, males are found to be larger in almost all the characters in Jalore and Jhunjhunu populations, whereas females tended to possess larger values in the Cutch sample. However, inter-population comparison indicated significant differences only for a few characters. In $R$. meltada pallidior, the male body parts are significantly larger in respect of head and body length and tail length $(P<0.01)$ in Churu-Jhunjhunu-Maulasar sample and tail length $(P<0.01)$ and hindfoot length $(P<0.05)$ in Gujerat population. Comparative study between populations indicated that only few cranial characters attained statistically significant differences.
\end{abstract}

\section{INTRODUCTION}

Three species of the genus Rattus are found in the fields in the Indian desert. The Cutch Rock-rat, Rattus c. cutchicus (W roughton, 1912) inhabit the cracks and crevices in the rocky habitat ( Prakash \& $\mathrm{R}$ a n a, 1972), $R$. meltada pallidior (Ryley, 1914), are found in the natural pastures and in cultivated fields. Rattus gleadowi (M u r a y, 1885), occur in the gravel patches in the sandy habitat ( $\mathrm{Prakash}$ et al., 1971). The present communication, incorporates analysis of data on the variations of body and cranial measurements of the first two species of field rodents. We have not been able to collect a large sample of $R$. gleadowi and hence this species has been left out for the present. 


\section{MATERIAL AND METHODS}

Rattus cutchicus were snap trapped from rocks at Jalore $\left(25^{\circ} 21^{\prime} \mathrm{N}-72^{\circ} 37^{\prime} \mathrm{E}\right)$ and Jhunjhunu $\left(28^{\circ} 08^{\prime} \mathrm{N}-72^{\circ} 23^{\prime} \mathrm{E}\right)$ in the Rajasthan desert. A comparison of various body and cranial measurements has been made with those of the sample from Cutch (Bhuj $-23^{\circ} 15^{\prime} \mathrm{N}-69^{\circ} 48^{\prime} \mathrm{E}$ ) as per the data presented by Ellerman (1961). Rattus meltada pallidior were colected from native pastures and irrigated crop fields at Churu $\left(28^{\circ} 18^{\prime} \mathrm{N}-74^{\circ} 58^{\prime} \mathrm{E}\right)$, Jhunjhunu, Maulasar $\left(27^{\circ} 24^{\prime} \mathrm{N}-74^{\circ} 35^{\prime} \mathrm{E}\right)$, Jadan $\left(25^{\circ} 47^{\prime} \mathrm{N}-73^{\circ} 20^{\prime} \mathrm{E}\right)$, Jalore, Bisalpur $\left(25^{\circ} 07^{\prime} \mathrm{N}-73^{\circ} 04^{\prime} \mathrm{E}\right)$ and a comparison has been done with the rodents collected from Palanpur $\left(24^{\circ} 10^{\prime} \mathrm{N}-72^{\circ} 26^{\prime} \mathrm{E}\right)$, Gujarat State (E llerman, 1961). All the methods and observations have already been explained in our earlier publications ( $\mathrm{R}$ a $\mathrm{n}$ a et al., 1970, 1975).

\section{RESULTS AND DISCUSSION}

\section{A. Rattus cutchicus cutchicus (W roug h to n, 1914)}

\section{Differences between Sexes}

Males in the Jalore and Jhunjhunu population are apparently larger in all the external body parts than their counterparts, except in respect of the ear, which is longer in Jhunjhunu females but the differences do not approach the level of significance (Table 1). Contrarily, females in Cutch population are bigger, though not significantly, in respect of head and body and tail lengths (Table 2). It is interesting to note that the sexual dimorphism percentage $(S D P)$ is much more apparent in respect of almost all the body measurements in the Jhunjhunu population $(-3$ to -8$)$ than those of Jalore (range -5 to -2$)$ and Cutch populations (range -1 to +4 ) (Table 2).

Similarly, most of the skull measurements of male rats from Jalore and Jhunjhunu samples are larger than those of the females (Table 1) but the difference in auditory length and the length of diastema only reach a level of significance $(P<0.05)$ and that too in the Jalore population only. Whereas, females are larger in cranial characters than the males belonging to Cutch sample (Table 1) but none of the character exhibited significant differences.

It is pertinent here to mention that the sexual dimorphism within a population are of greater magnitude in the Jalore sample (SDP range -14 to +17 ) followed by Jhunjhunu sample (SDP range -5 to +12 ) and that of Cutch $(-1$ to +4$)$ (Table 2).

\section{Differences between the Three Populations}

Although all the external body parts, except the ear, in the males of Jhunjhunu sample and that of females in the Cutch sample, are larger than their respective sexes in the other two populations yet no 


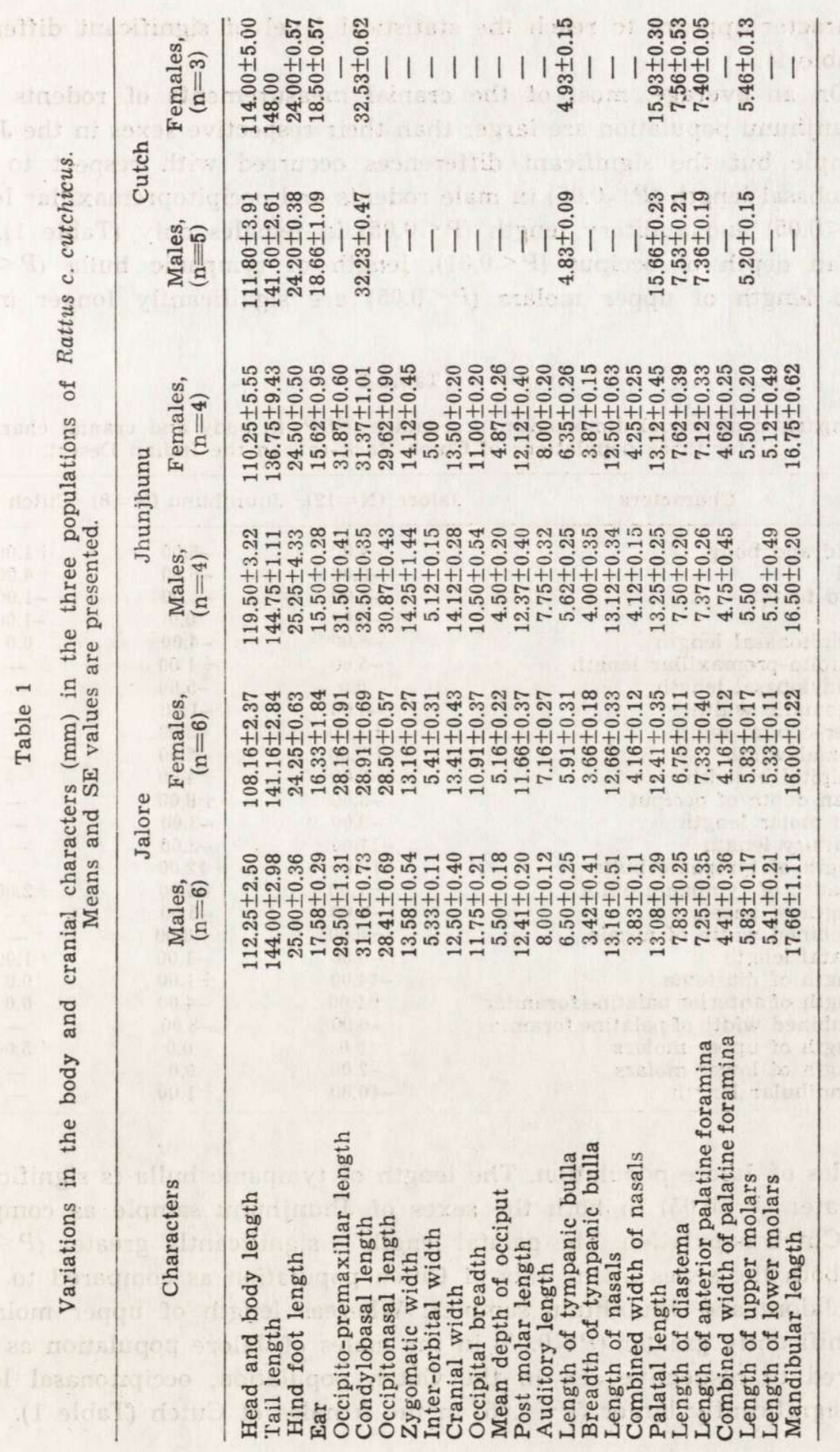


character appears to reach the statistical level of significant difference (Table 1).

On an average, most of the cranial measurements of rodents from Jhunjhunu population are larger than their respective sexes in the Jalore sample but the significant differences occurred with respect to condylobasal length $(P<0.05)$ in male rodents and occipitopremaxillar length $(P<0.05)$ and auditory length $(P<0.05)$ in females only (Table 1$)$. The mean depth of occiput $(P<0.01)$, length of tympanic bulla $(P<0.05)$ and length of upper molars $(P<0.05)$ are significantly longer in the

Table 2

Comparison of sexual dimorphism percentage (SDP) in body and cranial characters for three populations of Cutch Rock-rats in the Indian Desert.

\begin{tabular}{|c|c|c|c|}
\hline Characters & Jalore $(\mathrm{N}=12)$ & Jhunjhunu $(N=8)$ & Cutch $(\mathrm{N}=8)$ \\
\hline $\begin{array}{l}\text { Head and body } \\
\text { Tail } \\
\text { Hind foot } \\
\text { Ear } \\
\text { Occipitonasal length } \\
\text { Occipito-premaxillar length } \\
\text { Condylobasal length } \\
\text { Zygomatic width } \\
\text { Inter-orbital width } \\
\text { Cranial width } \\
\text { Occipital breadth } \\
\text { Mean depth of occiput } \\
\text { Post molar length } \\
\text { Auditory length } \\
\text { Length of tympanic bulla } \\
\text { Breadth of tympanic bulla } \\
\text { Length of nasals } \\
\text { Combined width of nasals } \\
\text { Palatal length } \\
\text { Length of diastema } \\
\text { Length of anterior palatine foramina } \\
\text { Combined width of palatine foramina } \\
\text { Length of upper molars } \\
\text { Length of lower molars } \\
\text { Mandibular length }\end{array}$ & $\begin{array}{c}-4.00 \\
-2.00 \\
-3.00 \\
-5.00 \\
-8.00 \\
-5.00 \\
0.0 \\
-4.00 \\
+1.00 \\
+7.00 \\
-7.00 \\
-3.00 \\
-3.00 \\
-11.00 \\
-10.00 \\
+7.00 \\
-4.00 \\
+8.00 \\
-6.00 \\
-14.00 \\
+1.00 \\
-6.00 \\
0.0 \\
-2.00 \\
-10.00\end{array}$ & $\begin{array}{c}-8.00 \\
-6.00 \\
-3.00 \\
0.0 \\
-4.00 \\
+1.00 \\
-5.00 \\
-1.00 \\
-3.00 \\
-5.00 \\
+4.00 \\
+8.00 \\
-3.00 \\
-3.00 \\
+12.00 \\
-4.00 \\
-5.00 \\
+3.00 \\
-1.00 \\
+1.00 \\
-4.00 \\
-3.00 \\
0.0 \\
0.0 \\
+1.00\end{array}$ & $\begin{array}{r}+1.00 \\
+4.00 \\
-1.00 \\
-1.00 \\
0.0 \\
- \\
- \\
- \\
- \\
- \\
- \\
- \\
+2.00 \\
- \\
+1.00 \\
0.0 \\
0.0 \\
+5.00 \\
- \\
-\end{array}$ \\
\hline
\end{tabular}

males of Jalore population. The length of tympanic bulla is significantly greater $(P<0.05)$ in both the sexes of Jhunjhunu sample as compared to Cutch population. The palatal length is significantly greater $(P<0.05)$ in both the sexes in the rats of Cutch population as compared to those of Jalore and Jhunjhunu samples. Whereas length of upper molars is significantly greater $(P<0.05)$ in the males of Jalore population as compared to respective sex in the Cutch population, occipitonasal length is significantly larger $(P<0.05)$ in the females of Cutch (Table 1). 
B. Rattus meltada pallidior (R y le y, 1912)

\section{Differences between Sexes}

Almost all the external body parts are larger in the males than the females in the three populations but the level of significance is attained by head \& body length and tail length in the Churu-Jhunjhunu-Maulasar $(C J M)$ population $(P<0.01)$ and tail length $(P<0.01)$ and hind foot length $(P<0.05)$ in Gujarat population (Table 3$)$. Negative values of sexual dimorphism percentage also confirm the above observations, i.e., the

Table 4

A comparison of sexual dimorphism percentage in body and cranial characters for three populations of Rattus meltada pallidior in Indian Desert.

\begin{tabular}{|c|c|c|c|}
\hline Characters & $\begin{array}{l}\text { Churu, } \\
\text { Jhunjhunu } \\
\text { Maulasar }\end{array}$ & $\begin{array}{l}\text { Jadan, } \\
\text { Jalore and } \\
\text { Bisalpur }\end{array}$ & Gujarat \\
\hline Head and body & -7.0 & -11.0 & -7.0 \\
\hline Tail & -7.0 & -5.0 & -16.0 \\
\hline Hind foot & -3.0 & -3.0 & -9.0 \\
\hline Ear & -1.0 & -1.0 & -13.0 \\
\hline Occipito-premaxillar length & -1.0 & -2.0 & - \\
\hline Condylobasal length & 0.0 & -1.0 & - \\
\hline Occipitonasal length & -2.0 & -2.0 & -8.0 \\
\hline Zygomatic width & +2.0 & -1.0 & - \\
\hline Inter-orbital width & +1.0 & -5.0 & - \\
\hline Cranial width & +2.0 & -2.0 & - \\
\hline Occipital breadth & -7.0 & 0.0 & - \\
\hline Mean depth of occiput & -2.0 & -4.0 & - \\
\hline Post molar length & -2.0 & -1.0 & - \\
\hline Auditory length & -8.0 & -2.0 & - \\
\hline Length of tympanic bulla & +7.0 & -10.0 & -4.0 \\
\hline Breadth of tympanic bulla & -3.0 & -7.0 & \\
\hline Length of nasals & -2.0 & -4.0 & - \\
\hline Combined width of nasals & +5.0 & +5.0 & - \\
\hline Palatal length & 0.0 & -1.0 & -8.0 \\
\hline Length of diastema & -3.0 & -3.0 & \\
\hline Length of anterior palatine foramina & -7.0 & -2.0 & -4.0 \\
\hline Combined width of palatine foramina & -4.0 & -3.0 & \\
\hline Length of upper molars & +8.0 & 0.0 & -8.0 \\
\hline Length of lower molars & -1.0 & & - \\
\hline Mandibular length & -2.0 & -4.0 & - \\
\hline
\end{tabular}

males are larger than the females in respective populations (Table 4). The variation in the size of various body parts is more marked in Jadan-Jalore-Bisulpur $(J J B)(S D P-11$ to -1$)$ as compared to that in the Gujerat (SDP range -16 to -7$)$ and $\mathrm{CJM}(-7$ to -1$)$ populations.

The skulls of male metads are larger than females in all the three localities, the difference is much more evident in the Gujerat and $J J B$ samples. The observations are supported by the SDP values also (Table 4). 


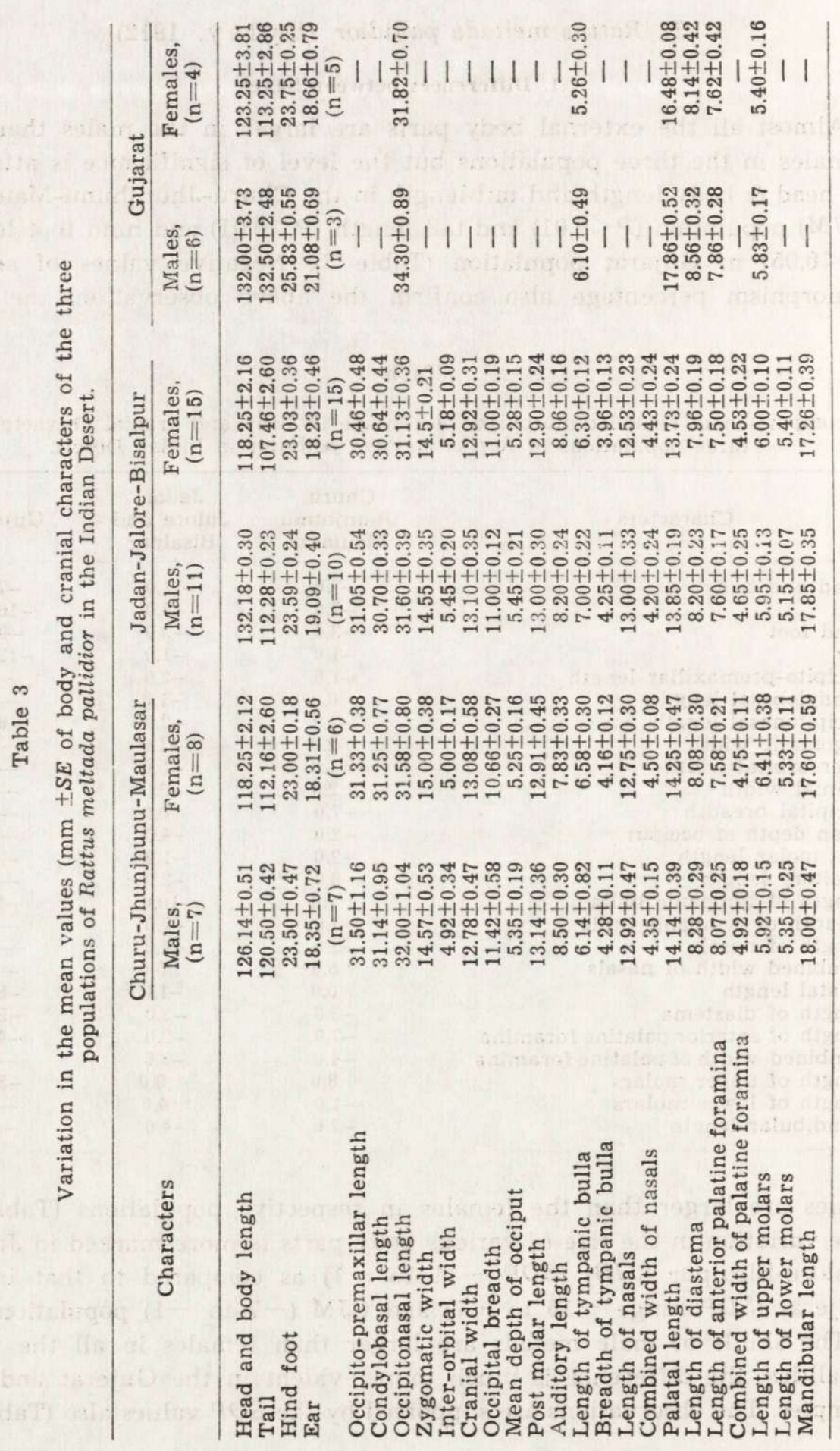


These range from -8 to -4 in Gujarat sample; -10 to +5 in JJB sample; and from -8 to +8 in the CJM population.

\section{Differences between the Three Populations}

All the external body parts are larger in the females of Gujarat sample than their respective sexes in other two populations but difference in none of the characters approach the level of statistical significance (Table 3). In case of male metads, however, the head and body length is largest in the $J J B$ sample. Further, this difference is statistically significant between the males of CJM and Gujerat samples in respect of tail length $(P<0.01)$, hind foot length $(P<0.01)$ and ear length $(P<0.05)$.

Most of the cranial measurements in the males and females of $C J B$ population are larger than their respective sexes in the $J J B$ population. However, significant differences between males of $C J M$ and Gujarat samples occurred with respect to palatal length $(P<0.01)$. Whereas, occipitonasal length $(P<0.05)$ and palatal length $(P<0.01)$ are significantly larger in the males of Gujarat population than in the males of $J J B$ sample, palatal length in the females of Gujarat is significantly larger $(P<0.01)$ than the females in the other two populations. Length of upper molars is significantly greater in the females of CJM $(P<0.05)$ and $J J B$ population $(P<0.01)$ than their respective sexes in Gujarat population. This significant difference might be due to their having significantly large palate (Table 3 ).

Acknowledgements: Authors wish to extend their gratitude to Dr. H. S. M a n in, Director of the Institute for providing necessary facilities.

\section{REFERENCES}

1. Prakash Ishwar, Gupta R. K., Jain A. P., Rana B. D. \& Dutta B. K., 1971: Ecological evaluation of rodent populations in the desert biome of Rajasthan. Mammalia, 35, 3: 382-423.

2. Prakash Ishwar \& Rana B. D., 1972: A study of field population of rodents in the Indian desert - II. Rocky and piedmont zones. Ztschr. angew. Zool., 59: 129-139.

3. Rana B. D., Prakash Ishwar \& J a in A. P., 1970: Morphological variation in Tatera indica indica $\mathrm{Hardwicke}, 1807$, inhabiting two types of Indian desert habitats. Acta theriol., 15, 28: 459-464.

4. Rana B. D., Jain A. P. \& Prakash I., 1975: Morphological variation in the Gerbils inhabiting the Indian desert. Acta theriol., 20, 10: 123-132.

Accepted, June 26, 1974.

Animal Ecology Section,

Central Arid Zone Research Institute,

Jodhpur, India. 
A. P. JAIN, Ishwar PRAKASH i B. D. RANA

ZMIENNOSC MORFOLOGICZNA PRZEDSTAWICIELI RODZAJU RATTUS

Z PUSTYNI INDYJSKIEJ

\section{Streszczenie}

Badano porównania wymiarów ciała i czaszki u trzech populacji Rattus c. cutchicus (Wroughton, 1912) i Rattus meltada pallidior ( $\mathrm{R}$ y ley, 1914) lowionych na pustyni indyjskiej (Pustynia Thar). U $R$. c. cutchicus samce z populacji lowionej w okolicach Jalore i Jhunjhunu są większe niż samice, w przeciwieństwie do populacji Cutch, gdzie zależności były odwrotne (Tabela 2). Tym niemniej porównania pomiędzy poszczególnymi populacjami wskazują, że zróżnicowanie jest istotne tylko $\mathrm{w}$ odniesieniu do niewielu wskaźników (Tabela 1). U $R$. meltada pallidior samce z populacji Churu, Jhunjhunu i Maulasar mają istotnie większą długość ciała i ogona a $\mathrm{z}$ okolic Gujarat znamiennie większą długość ogona i stopy w porównaniu do samic (Tabela 4). Porównawcze badania cech czaszkowych wskazują, że różnice między populacjami odnoszą się tylko do niewielu wskaźników (Tabela 3). 